\title{
Effects of a syllabic highlight technique in word reading of beginning readers
}

Wania Nogueira Lopes. Secretaria da Educação do Estado de São Paulo Sylvia Domingos Barrera. Universidade de São Paulo, Ribeirão Preto

\section{Abstract}

The role of the syllable in written word recognition is an open question in psycholinguistic studies about reading. We analyzed the effects of a syllabic highlight technique on the reading performance of students in the 2nd degree of elementary school. Seventy-two children (mean age of 7,7 years) performed a collective test to identify their reading level (TCLPP). Afterwards, they were distributed in two equivalent groups and individually submitted to an oral words and pseudowords reading test (LPI), written with and without the technique, according to a crossover design. Syllabic highlight technique had significant positive effects on reading performance, particularly for less skilled readers. The repetition of the task enhanced the effectiveness of the technique. The results support the hypothesis that the syllable is an important linguistic unit in word recognition in Brazilian Portuguese. The syllabic highlight can be an effective strategy to construction of material for teaching and remediation of reading difficulties.

Keywords: reading learning; word recognition; syllable.

\section{Resumo}

Efeitos de uma técnica de destaque silábico na leitura de palavras de crianças em processo de alfabetização. O papel da sílaba na leitura de palavras é uma questão em aberto na literatura. Analisamos os efeitos de uma técnica de destaque silábico, sobre o desempenho em leitura de alunos do $2^{\circ}$ ano do Ensino Fundamental. Setenta e duas crianças (média de 7,7 anos) realizaram um teste coletivo para identificação do nível de leitura (TCLPP). Após, foram distribuídas em dois grupos equivalentes e submetidas a um teste de leitura de palavras e pseudopalavras (LPI), com e sem uso da técnica, conforme delineamento crossover. A técnica silábica teve efeitos positivos significativos sobre o desempenho em leitura, particularmente para os leitores menos hábeis. A repetição da tarefa potencializou a eficácia da técnica. Os resultados suportam a hipótese de que a sílaba é uma unidade linguística importante no reconhecimento de palavras no português brasileiro. $O$ destaque silábico pode ser uma estratégia eficaz na elaboração de material para o ensino e remediação das dificuldades de leitura.

Palavras-chave: aprendizagem da leitura; reconhecimento de palavras; sílaba.

\section{Resumen}

Efectos de una técnica de destaque silábico en la lectura de niños en proceso de alfabetización. El papel de la sílaba en la lectura es una cuestión abierta en la literatura. Analizamos los efectos de una técnica de destaque silábico, sobre el desempeño en lectura de 72 alumnos del $2^{\circ}$ año de la Enseñanza Fundamental (media de 7,7 años). Estos realizaron una prueba colectiva para identificar su nivel de lectura (TCLPP). Después, fueron distribuidos en dos grupos equivalentes y sometidos a una prova de lectura de palabras y pseudo-palabras (LPI), con y sin uso de la técnica, conforme delineamiento crossover. La técnica silábica tuvo efectos positivos significativos, particularmente para los lectores menos hábiles. La repetición de la tarea potenció su eficacia. Los resultados apoyan la hipótesis de que la sílaba es una importante unidad lingüística en el reconocimiento de las palabras en portugués de Brasil. El destaque silábico puede ser una estrategia eficaz en la elaboración de material para la enseñanza y remediación de las dificultades de lectura.

Palabras clave: aprendizaje de la lectura; reconocimiento de palabras; sílaba. 
Learning to read in alphabetic systems is based on the understanding that writing represents the sounds of speech. To read it is necessary to relate the orthographic patterns of the written words to the phonological and semantic representations associated with them. These cognitive treatments lead to understanding, which is the ultimate goal of reading. Thus, word recognition consists of a fundamental ability in learning to read (Maluf, 2005).

Two broad and complementary processes are involved in word recognition: the phonological recoding (or simply decoding) of new words and the visual orthographic processing of familiar words. These processes were originally proposed as part of the double-route reading models (Coltheart, 2013; Ellis \& Young, 2014) and allow explain not only the performance of normal reading, but also some disturbances in reading words. According to these models, two reading routes are involved in the visual recognition of words: the lexical route, which allows automatic reading of familiar and irregular words stored in the visual-orthographic lexicon (most used by the most fluent readers); and the phonological route that allows the reading of regular words and pseudowords, based on letter/sound decoding (most used by early readers) (Coltheart, 2013; Pritchard, 2012). For a word to be read, it is first analyzed in its units of visual characteristics and then processed through one of the routes or both.

In this approach, reading learning is described as the progressive development of phonological recoding abilities, which uses different units of grapho-phonological processing, leading to automatic word recognition, through the establishment of connections between the orthographic and phonological segments (Morais, 2003). In his theory of self-learning, Share (1995) argues that phonological recoding provides the main basis for the well-detailed storage of orthographic representations in long-term memory, which is imperative to skillful reading.

One of the most well-known and successful models for explaining word reading is the Dual-route Cascaded model (DRC) (Coltheart, 2013), which received a computational component to model the orthographic learning mediated by phonological (the hypothesis of self-learning) (Coltheart 2013; Pritchard, 2012). The L-DRC (Learning - Dual Route Cascaded) model seeks to clarify the degree of contribution of the phonological route to the recognition and learning of irregular words as well as the role of contextual support. Partial decoding (activation of phonemic nodes in the phonological lexicon) seems to aid this process (Pritchard, 2012).
The role of phonology, more specifically the size of the linguistic units used by readers during access to word representations in the mental lexicon has been the focus of several studies (Duncan, Colé, Seymour, \& Magnan, 2006; Ecalle \& Magnan, 2007). Some authors maintain that phonological units larger than phonemes, such as syllables and rhymes, would play a fundamental role in reading learning, since they would be functional units of access to the lexicon, even when the decoding procedure is not dominant in reading (Chetail, 2014, Chetail \& Mathey, 2009a, Doignon-Camus \& Zagar, 2006, 2014). There is evidence that the syllable would be a less abstract phonological unit and therefore more accessible to consciousness than the phoneme in the processing of language, because it is a unit of natural segmentation of the spoken language. According to this current, the reading procedure using larger phonological units (syllables and rhymes) would be the first step in establishing correspondences between oral and written language. The ability to orally manipulate syllables and rhymes would make it possible to identify in written words orthographic patterns that correspond to these sound units. Authors such as Doignon-Camus and Zagar (2006) suggest that children, already at the end of the first year of literacy, perceive the syllables in sequences of letters and that this perception can be reinforced through the teaching methodology employed.

Likewise, studies on phonological awareness reveal that children present more difficulties in tasks of phonemic segmentation than in tasks involving syllabic manipulation. In addition, there is evidence that French, English and Brazilian preschool children present better performance in syllable identification and counting when compared with phonemes (Barrera \& Santos, 2014; Ecalle, \& Magnan, 2007; Santos, 2017; Siccherino, 2017).

On the other hand, several studies have pointed to phonemic awareness, along with letter knowledge, as the most important predictors of reading learning (Ehri \& Roberts, 2006; Kim, Petscher, Foorman, \& Zhou, 2010; Morais, Leite, \& Kolinsky, 2013). Likewise, several studies do not confirm the early use of syllables in the recognition of larger orthographic units, but they support the idea that children at the beginning of reading learning use a strategy based on letters-sounds correspondences while larger units would be used later, as a second strategy (Ehri, 2013; Yoncheva, Wise, \& McCandliss, 2015).

It is also important to note the language in which the research is developed, due to the differences in syllabic salience among them. French studies reported above 
(Doigon-Camus \& Zagar, 2006; Ecalle \& Magnan, 2007) seem more favorable to the defense of the importance of syllable in reading learning than English studies, which usually support the phoneme or other smaller units than syllable (onset and rime) in the basis of this learning. In Brazil, results of a recent survey with 90 preschoolers (mean age 4 years and 5 months) also suggest that the teaching of orthographic mapping of phonemes is more effective than that of syllables (Sargiani, 2016).

In fact, the discussion in the literature about the linguistic unit more adequate to promote the process of phonological recoding and, consequently, to promote the learning of reading, can not be done without taking into account aspects specific to the different languages, since this definition seems to be closely related to the dimensions of syllabic complexity (rules of combining vowels and consonants) and to the orthographic depth (greater or lesser degree of regularity in the correspondences between graphemes and phonemes) of each language (Shany \& Share, 2011; Ziegler, Perry, Jacobs, \& Brown, 2001). Seymour (2013) demonstrated that the process of decoding, at the beginning of literacy, happens in a slower and less efficient way in certain languages in relation to others. The presence of clearly defined syllables containing few consonant groups is ideal so that the correspondences between graphemes and phonemes are established and the fusion of phonemes transformed into spoken segments.

The use of larger orthographic units, such as the syllable, seems to reduce the cognitive cost of letterto-letter decoding, and may also be a possibility of transition between phoneme based reading strategies used by the most beginning readers and lexical reading strategies used by skilled readers. Studies emphasizing the syllabic units suggest that beginning readers benefit from the syllable index, probably because they still have problems for organize the sequence of letters into syllables, i.e, determining where a syllable ends and another begins (Chetail, \& Mathey, 2009b; Ecalle, Magnan, $\&$ Calmus, 2009). Reading training with an emphasis on syllabic units seems to be also indicated to increase decoding efficiency in beginner readers with some difficulties (Bhattacharya \& Ehri, 2004; Ecalle et al., 2009).

In spite of the controversies about the relative importance of syllabic and phonemic analysis in reading learning, it is possible to consider that the syllable is an important phonological unit of the spoken language, especially in linguistic systems where the syllables are clearly defined, as is the case of Brazilian Portuguese.
Despite this, little is known about the activation of syllables during reading in children speaking this language. In this way, researches that seek to clarify and bring greater understanding about the role of the syllabic organization in the phonological and orthographic representations used in the cognitive processes involved in the learning of reading are desirable.

Thus, the purpose of this study was to analyze the effects of a technique highlighting syllabic segmentation in written words, on the reading performance of students in the literacy process. Our hypothesis is that the use of the technique may have a facilitating effect on phonological recoding, favoring performance in reading words and pseudowords, especially in the case of less skilled readers, who still have difficulties with reading phonological strategies.

\section{Methods}

\section{Participants}

The sample was composed by 72 children, mean age of 7.7 years (SD of 0.5 years), of both sexes, students from four classes of the 2 nd degree of a public elementary school in a city of São Paulo state (Brazil), chosen for convenience.

The school uses the didactic material of the Read and Write Program elaborated by the Department of Education of the State of São Paulo. The assumptions and objectives of this material are convergent with a literacy approach based on words and texts (global method) where writing is not seen as a code to be deciphered.

The inclusion criteria to participate in the research were: having regular school attendance, not having perceptual or cognitive deficits confirmed by medical report, and not completely failing in the word reading tasks (TCLPP and LPI). All children $(n=99)$ enrolled in 2 nd degree were invited to participate in the study. Twenty-six were unable to complete the tasks of reading words, reducing the sample to 72 children.

The 72 participants were divided into two groups: Group $1(n=37)$, with a mean age of 7.73 years $(S D=0,45), 51 \%$ of female participants and Group 2 $(n=35)$, with a mean age of 7.74 years $(S D=0.56)$ and $66 \%$ of female participants. The groups were composed aiming to balance the participants according their TCLPP scores.

The study was approved by the Research Ethics Committee (CAAE: 43621915.3.0000.5407), and all 
ethical procedures and principles for conducting research with human beings were followed. Institutional and parent authorizations were obtained.

\section{Study Design}

The study followed an experimental $2 \times 2$ crossover design. In this model, all participants receive two types of treatment, defined by two different sequences in two different periods of time, in order to compare the effects of the treatments. This design was chosen because it has the advantage of controlling the variability among subjects, favoring to identify the effects of the treatment, since it allows to reduce the residual variance (Armitage, Berry, \& Matthews, 1971/2002).

\section{Instruments}

Test of Words and Pseudowords Reading Competence (TCLPP). The TCLPP (Seabra \& Capovilla, 2010) consists of 78 items (eight for training and 70 for testing), consisting of a combination of a figure and a written element, which can be word (appropriate or not to the corresponding figure) or pseudo-word. The child's task is to mark with a $\mathrm{C}$ the words considered correct to name the figures, and to mark with an $\mathrm{X}$ the words considered incorrect. Each correct answer is worth one point. The total of hits allows the classification of the child in different levels of reading. Seabra and Capovilla (2010) reported adequate evidence of validity and reliability of the test, in addition to presenting normative data for the Brazilian population.

Isolated Words Reading Task (LPI). The LPI task (Salles, Piccolo, Zamo, \& Toazza, 2013) evaluates the accuracy in oral reading of words and pseudowords that vary in their regularity degree (regular and irregular stimuli), lexicality (real words and pseudowords), extension (short stimuli, with two syllables, and long, with three or more syllables) and frequency of occurrence in the language (frequent and non-frequent words). The test consists of 60 stimuli, 20 regular words, 20 irregular words and 20 pseudowords. The maximum score is 60 points. In Salles, Piccolo, Zamo e Toazza (2017), studies are reported that demonstrate adequate evidence of validity and reliability of the test, as well as normative data of this instrument for the Brazilian population from the 1st to the 7th degree of Elementary School.

LPI with syllabic coloring technique (LPI-TCS). An adapted version of the LPI task was developed to evaluate reading performance using a syllabic coloring technique (TCS) for the writing of words and pseudowords. In this adaptation, the syllables of each word were alternately written in the colors red and blue, according to the following examples: (words) campo (field), operação (operation), grade (grid), bosque (grove), velho (old), exemplo (example); (pseudowords) tapi, cusbe, prantorca, brele, nefoxosa, tonecote. Scoring followed the same criteria as the conventional LPI task described above.

Audacity Multiplatform Software. For the recording of the participants' answers in LPI and LPI-TCS, the Audacity 2.1.1, free and open source multiplatform software was used. Thus, it was possible to record the reading aloud and the time in milliseconds, and subsequent counting of the total hits in the reading.

\section{Procedures}

Data collection took place in two phases. Initially, the TCLPP was applied in small groups, which allowed the classification of the participants in different levels of reading, using as criteria the expected values for the school grade. From this initial classification the children of each class were divided into two groups (G1 and G2) in order to obtain equivalence between the groups, that is, the children were allocated in a balanced way in each group in function of their results in TCLPP.

In the second phase, the children were individually submitted to two applications of the LPI task, one in its usual version and the other with the syllabic coloring technique. The applications occurred with a mean interval of 13 days (wash out), seeking to maximize the effects of forgetting the test (Mansur-Alves, Flores-Mendoza, \& Tierra-Criollo, 2013). G1 started the reading task with syllabic coloring technique (LPI-TCS) and G2 without the syllabic coloration strategy (LPI). After the wash out period, the tasks were reapplied in the inverse form to the children in each group. The words were displayed individually, in Times New Roman font, black, size 96, on white background, in lowercase letters, on the computer screen. When using the syllabic staining technique, the syllables were alternately written in red and blue. The time of presentation of each word depended on the child's response; the researcher pressed a key after each reading and thus, a new word appeared on the screen. The responses were recorded and the recording was used for later transcription and counting of hits.

\section{Data Analysis}

The t-test for independent samples (G1 vs G2) was used to verify the existence (or not) of significant differences in the participant's reading performance derived of the treatment (reading without technique vs with technique), of the period (first reading vs. second reading) and the interaction between treatment and period 
(Armitage et al., 1971/2002). In the case of the existence of this interaction, the carryover effect (also called the residual effect) would be considered, because it is an indication that the treatment carried out in the first period still has a remaining effect on the treatment carried out in the second period. In these cases, the measure of separability between treatment effects and period can be estimated from the Omnibus test. The effect size was determined by the calculation of Cohen's $d$, whose results were interpreted as: insignificant $(<0.19)$; small $(0.20$ to 049$)$, medium ( 0.50 to 0.79$)$, large (0.80 to 1.29 ) and very large (>1.30) (Espírito-Santo \& Daniel, 2015). The level of significance previously established for all analyzes was 0.05 .

The option to use parametric tests on the analysis performed was supported by the Central Limit Theorem (Dancey \& Reidy, 2006; Massad, Ortega, $\&$ Silveira, 2004), when the sample size is sufficiently large (> 30) to allow a normal distribution of residuals.

\section{Results}

Preliminary analyzes confirmed that G1 and G2 had equivalent initial readings (baseline measurements), because no statistically significant differences were observed in the performance of the groups in the TCLPP, as indicated by the results of the comparisons performed using the $\mathrm{t}$ test $(t=-0.957 ; d f=70, p=0.342)$.

Table 1 shows the average results obtained by the total sample and by the two groups (G1 and G2) in the LPI, both in reading with technique $(A)$ and without technique (B) of syllabic staining, in function of different types of stimuli (total words, regular words, irregular words and pseudowords). The table also shows the mean scores of the subgroups according to the initial reading level as measured by the TCLPP (good readers $\mathrm{x}$ regular readers).

Table 1. Mean and Standard Deviation of Results Obtain by Participants in LPI Test

\begin{tabular}{|c|c|c|c|c|}
\hline \multirow{2}{*}{ LPI } & \multicolumn{2}{|c|}{ LPI - TCS (N=72) } & \multicolumn{2}{|c|}{ LPI (N=72) } \\
\hline & Mean & (SD) & Mean & (SD) \\
\hline Total Score $(0-60)$ & 44.0 & (11.7) & 42.3 & $(12.8)$ \\
\hline Irregular words (0-20) & 12.8 & (5.1) & 12.3 & (5.3) \\
\hline Pseudowords (0-20) & 14.2 & (4.3) & 13.4 & (4.9) \\
\hline LPI & $\begin{array}{c}\text { LPI-TCS } \\
\text { Mean (SD) }\end{array}$ & $\begin{array}{c}\text { LPI } \\
\text { Mean (SD) }\end{array}$ & $\begin{array}{c}\text { LPI } \\
\text { Mean (SD) }\end{array}$ & $\begin{array}{c}\text { LPI-TCS } \\
\text { Mean (SD) }\end{array}$ \\
\hline Total score (0-60) & $44.4(11.3)$ & $44.9(11.9)$ & $39.6(13.3)$ & $43.6(12.2)$ \\
\hline Regular words (0-20) & $17.3(2.9)$ & $17.3(3.4)$ & $16.0(3.8)$ & $16.7(3.4)$ \\
\hline LPI & $\begin{array}{c}\text { LPI - TCS } \\
\text { Mean (SD) }\end{array}$ & $\begin{array}{c}\text { LPI } \\
\text { Mean (SD) }\end{array}$ & $\begin{array}{c}\text { LPI - TCS } \\
\text { Mean (SD) }\end{array}$ & $\begin{array}{c}\text { LPI } \\
\text { Mean (SD) }\end{array}$ \\
\hline Total Score $(0-60)$ & $38.3(11.5)$ & $36.3(12.5)$ & $51.9(6.1)$ & $50.7(7.3)$ \\
\hline Regular words (0-20) & $15.7(3.5)$ & $15.2(4.0)$ & $18.7(1.4)$ & $18.7(1.6)$ \\
\hline Irregular words (0-20) & $10.3(4.7)$ & $9.8(5.0)$ & $16.5(3.1)$ & $15.7(3.4)$ \\
\hline Pseudowords (0-20) & $12.3(4.4)$ & $11.3(4.8)$ & $16.8(2.4)$ & $16.3(3.2)$ \\
\hline
\end{tabular}

Note: LPI = Isolated Word Reading Test; LPI-TCS = Isolated Word Reading Test with Syllabic Colored Technique; TCLPP = Test of Words and Pseudowords Reading Competence.

From a general analysis, we can observe that, for the total sample, and particularly for $\mathrm{G} 2$, whose second reading was performed using the technique of prominent syllabic, the use of this strategy seems to have facilitated the reading of all types of words (total score, regular words, irregular words and pseudowords). This superiority was not observed in the results of the G1, which made the first reading using the technique. These 
results suggest that the period in which it was the technique was used also had interference in the results obtained. A visual comparison of the results of the groups of good readers and those with more difficulties also suggest greater effects of the technique for the latter.

Table 2 below shows the results of the inferential analyzes performed using the $t$ test, considering the treatment effects (with technique (A) vs. without technique (B)), period (first reading vs. second reading) and interaction (treatment vs. period) in the total sample $(N=72)$. The results indicated a statistically significant difference in the reading task (LPI) in favor of the use of the syllabic staining technique (treatment) for all categories of investigated words, except for regular ones. However, also in this case the $\mathrm{p}$ value was very close to the statistical significance $(p=0.059)$. In the case of the effect of the period on LPI performance, the differences between the groups were also significant for all categories of words, indicating higher results obtained with the second reading. For all stimulus categories, both the effects of the treatment and the period presented magnitudes ranging from moderate to (very) large, demonstrating that both the use of the syllabic coloring technique and the reading for the second time favored the performance in reading words. Finally, it should be noted that, in the total sample, analyzes of the interactions between treatment and period did not present significant results.
Table 2. Results of Observed Effects (d) in Isolated Word Reading Test (LPI) Achievement in General Sample

\begin{tabular}{llccc}
\hline LPI & Effects & $\boldsymbol{t}$ - Test & Sig. & $\boldsymbol{d}$ \\
\hline Total Score & Treatment & 5.240 & $<0.001^{* * *}$ & 1.24 \\
& Period & -7.437 & $<0.001^{* * *}$ & 1.76 \\
& Treat. ${ }^{*}$ Period & 1.058 & 0.294 & - \\
Regular Words & Treatment & 1.917 & 0.059 & 0.45 \\
& Period & -2.308 & $0.024^{*}$ & 0.54 \\
& Treat. ${ }^{*}$ Period & 1.234 & 0.221 & - \\
Irregular Words & Treatment & 3.367 & $0.001^{* *}$ & 0.79 \\
& Period & -5.758 & $<0.001^{* * *}$ & 1.36 \\
& Treat. ${ }^{*}$ Period & 1.025 & 0.309 & - \\
Pseudowords & Treatment & 2.998 & $0.004^{* *}$ & 0.71 \\
& Period & -3.407 & $0.001^{* *}$ & 0.80 \\
& Treat. ${ }^{*}$ Períod & 1.180 & 0.242 & - \\
\hline Note: ${ }^{*} p<0.05 ;{ }^{* *} p<0.01 ;{ }^{* * *} p<0.001$. & &
\end{tabular}

Considering now the level of reading of the participants (Table 3), the inferential analyzes confirm the greater effectiveness of the technique for the readers with greater difficulties. Table 3 shows the results of the $t$ test with regard to the effects of the treatment (with technique vs. no technique), indicating that, in the case of less skilled readers (regular readers according to TCLPP), there were significant differences in favor of the technique for all categories of words. The effects of period (1st reading vs. 2 nd reading) also presented statistical significance for almost all stimuli, except regular words. The interaction between treatment vs. period showed no significant effects for this subgroup.

Table 3. Results of Observed Effects (d) in Isolated Words Reading Test (LPI) Achievement According to the Baseline Reading Level of Participants

\begin{tabular}{|c|c|c|c|c|c|c|}
\hline \multicolumn{4}{|c|}{$\begin{array}{l}\text { Regular readers (TCLPP) } \\
\qquad(n=42)\end{array}$} & \multicolumn{3}{|c|}{$\begin{array}{l}\text { Good readers (TCLPP) } \\
\qquad(n=30)\end{array}$} \\
\hline & $t$ & $\mathbf{P}$ & $d$ & $t$ & $p$ & $d$ \\
\hline \multicolumn{7}{|l|}{ Total Score } \\
\hline Treatment & 5.677 & $<0.001^{* * *}$ & 1.76 & 2.086 & $0.046^{*}$ & 0.76 \\
\hline Period & -7.014 & $<0.001^{* * *}$ & 2.17 & -3.870 & $0.001^{* *}$ & 1.42 \\
\hline Treat. ${ }^{*}$ Period & 1.380 & 0.175 & - & 1.299 & 0.208 & - \\
\hline \multicolumn{7}{|l|}{ Regular Words } \\
\hline Treatment & 2.147 & $0.038^{*}$ & 0.67 & -0.055 & 0.554 & - \\
\hline Period & -1.663 & & - & -2.323 & $0.028^{*}$ & 0.85 \\
\hline Treat. ${ }^{*}$ Period & 1.338 & & - & 1.699 & 0.100 & - \\
\hline \multicolumn{7}{|l|}{ Irregular Words } \\
\hline Treatment & 2.330 & 0.104 & 0.72 & 2.476 & $0.020^{*}$ & 0.91 \\
\hline Period & -4.569 & 0.188 & 1.42 & -3.317 & $0.003^{* *}$ & 1.21 \\
\hline Treat. ${ }^{*}$ Period & 1.300 & 0.201 & - & 1.279 & 0.211 & - \\
\hline
\end{tabular}


Table 3. Continuation

\begin{tabular}{|c|c|c|c|c|c|c|}
\hline \multicolumn{4}{|c|}{$\begin{array}{l}\text { Regular readers (TCLPP) } \\
\qquad(n=42)\end{array}$} & \multicolumn{3}{|c|}{$\begin{array}{l}\text { Good readers (TCLPP) } \\
\qquad(n=30)\end{array}$} \\
\hline & $t$ & $P$ & $d$ & $t$ & $p$ & $d$ \\
\hline \multicolumn{7}{|l|}{ Pseudowords } \\
\hline Treatment & 2.992 & $0.005^{* *}$ & 0.93 & 1.304 & 0.203 & \\
\hline Period & -3.467 & $0.001^{* *}$ & 1.07 & -1.178 & 0.249 & - \\
\hline Treat. ${ }^{*}$ Period & 1.653 & 0.106 & - & 0.673 & 0.508 & - \\
\hline
\end{tabular}

Note: ${ }^{*} p<0.05 ;{ }^{* *} p<0.01 ;{ }^{* * *} p<0.001$

Among the good readers, in turn, there were significant differences in reading performance in favor of the technique $(p<0.05)$ only in the total of hits and irregular words scores (Table 3 ). The period effect was significant for almost all categories of words, except for pseudowords. In this subgroup there was also no significant interaction between treatment and period. It is noteworthy that, except for the irregular words, the size of the treatment effect (d) on the performance of the less skilled readers was much higher than in the case of the good readers, confirming the greater efficiency of the syllabic coloring technique for the first ones.

Due to the article size limit we will not display the results of reading time analysis. We advance, however, that the technique had no significant effect on reading time. However, the reading time was significantly shorter in the second reading of the stimuli, with or without technique.

\section{Discussion}

The results suggest that the syllabic coloring technique can facilitate the performance in reading words and pseudowords in children in the literacy process. These results are in line with previous studies on the function of the syllable in the recognition of isolated words (Battacharya \& Ehri, 2004; Chetail \& Mathey, 2009a; Doignon-Camus \& Zagar, 2006). It was also found that the period (second reading) also facilitated the readers' performance. No interaction effects between treatment (technique) and period were observed. We conclude that the moderate to large effects observed with the use of the syllabic highlight in the reading of most stimuli categories do not need to be relativized. The lack of interaction seems to indicate that regardless of the period, the technique had positive significant effects, as did the period, since reading for the second time, regardless of with or without technique, also had positive significant effects.
Considering the classification of the initial reading level, it was observed that both groups of readers benefited from the syllabic highlight, but the less skillful readers were more significantly assisted and for all categories of words, while for good readers this effect was only in the case of total score and irregular words (not affecting the reading of regular words and pseudowords). These findings are in line with the results obtained by Chetail and Mathey (2009b), who obtained a greater effect of facilitating the reading of words with syllabic borders demarcated in a congruent way among the new readers with lower level of reading proficiency.

The results obtained can be explained by the double-route reading model, which explains that the primary procedure used by the beginning readers is the grapheme-phoneme conversion, that is, the phonological route (Coltheart, 2013). Thus, the technique seems to have strengthened the mechanism of phonological recoding by means of the syllabic highlighting, helping the organization of the letter sequences within the words, which is a difficulty for these readers. For good readers, who have more mastery of decoding skills, the technique has not had such an important effect (except for irregular words, which will be discussed later).

The results of period effects of regular words (Table 3) show an interesting fact. There was no effect of period for the readers considered weak in the reading of this type of words, but only for the good readers. For the latter, who already have developed broader reading strategies and could read the words more automatically (Ehri, 2013), the second exposure to the test seems have been able to assist them storing the orthographic representations of these words in the orthographic lexicon, especially in the case of less frequent ones.

Considering the effect of the technique on reading irregular words (Table 3 ), both groups of readers benefited, with moderate to large effect size values (in the case of good readers). The results show that the highlighting of the syllabic units also favored the 
recognition of this type of word, strengthening the hypothesis that the reading of irregular words also depends, to some degree and especially in the case of early readers, on the mechanism of recoding phonological. These findings can be supported by the double-route L-DRC model, which explains the reading of irregular words by means of the self-learning theory, specifying the degree of contribution of partial decoding by the activation of phonemic nodes in the phonological lexicon (Pritchard, 2012). Children in the process of literacy learn to use the knowledge of the relationships between letters and sounds to perform partial decoding, especially in case of the irregular words and complex spellings. Using these "approximate" phonological representations, they can generate pronunciations that approach the target word until they produce a word that corresponds to one that is stored in the mental lexicon and that makes sense in the context in which it appears (Tunmer \& Chapman, 2012). When the contextual support is zero (as in the case of isolated word reading) or very low, there is a reduction in the inhibition of phonemes in the phonological lexicon, which increases the opportunity for partial decoding of irregular words, since the phonemes activated by the sub-lexical route (phonological route) activate several nodes of neighboring words in the phonological lexicon (especially the nodes that are phonological neighbors of regular pronunciation) (Pritchard, 2012). This seems to have been the case with less skillful readers, as they showed a statistically significant increase in the scores of correct irregular words when reading the LPI with the technique, but they also generated, in many cases, "approximate" pronunciations of words, besides have made several regularization errors (commons in case of reading by the phonological route).

According to Share (1995), early readers find it more difficult to learn new irregular words compared to skill readers because of poor decoding ability. For good readers, who read words more automatically, the technique seems to have favored a closer reading of irregular words, probably because syllabic segmentation "forced" them to focus their attention on the sequences of letters, activating the process of phonological recoding, making it possible to avoid errors observed in nontechnical reading, probably due to the frequency effect.

It is worth noting the significant interference of the period effect on the reading of irregular words, both for the good readers and the less skilled, showing that the second reading of the test functioned as a learning mechanism to acquire spelling knowledge of the words. According to some studies, the number of exposures required for visual forms of new words (spelling knowledge) to be stored in memory is very low and can range from one to five exposures (Cunningham, 2006; Kyte \& Johnson, 2006; Nation, Angell, \& Castles, 2007).

Regarding the efficacy of the technique on the performance in pseudowords reading, the results were similar to those of regular words, since there was an effect of the technique only for the more beginner readers. For good readers, no significant effect was found on the performance of pseudowords. These findings also find support in the theoretical double-route model, which explains that pseudowords can only be read using a grapheme-phoneme conversion procedure, since these words are not real and are therefore not stored in the mental lexicon. In this way, the use of the technique, along with the repetition, favored the decoding procedure, facilitating the reading of the pseudowords for the more beginner readers, especially those who read with the technique in the second period. For the good readers, whose decoding procedure was already well developed, there was no facilitation with the use of the technique.

There is a repertoire of experimental studies that suggest the use of distinct cognitive processes in the fluent reading of shallow and deep orthographies, and that in the course of reading learning, the size of the sub-lexical units used varies according to language, depending on but also the complexity of its syllabic structure (Shany \& Share, 2011; Ziegler, et al., 2001). For example, French is a language with defined limits of syllables and several studies indicate that they may be the most important unit in word recognition in early readers (Doignon-Camus \& Zagar, 2006). Portuguese is also considered a language with simple syllabic complexity and partially deep spelling, very similar to French (Seymour, 2013; Snowling \& Hulme, 2013). Therefore, the syllable also seems to be an important linguistic unit in the learning of reading in Brazilian Portuguese speakers.

\section{Final considerations}

The present study allowed identify the efficacy of the syllabic coloring technique as an effective resource in facilitating reading in children in the literacy process, especially in the case of less skilled readers. The effects of the technique suggest that the syllable is an important linguistic unit in the process of word recognition 
in Brazilian Portuguese. Thus, the explicit teaching of phonological/orthographic correspondence of syllabic units can facilitate the process of phonological recoding during reading learning.

The results support the hypothesis that the use of syllabic highlighting can be a useful strategy in the elaboration of methodologies and didactic material for teaching reading, particularly for the development of word recognition skills in children at the beginning of the literacy process or with reading difficulties. The syllabic prominent strategy can facilitate the organization of the letter sequences within the words for the less skilled readers and induce the most skillful readers to focus attention on word composition, reducing errors in reading without using this strategy. In fact, a single exposure to the word with the highlighted syllable increased the number of participants' correct answers. These results suggest that if the school prioritized the teaching of smaller units, such as phonemes and syllables, reading learning could be more efficient.

One limitation of the study is that the participants' intellectual level was not controlled, which could have served as another criterion for balancing the groups, in addition to the initial reading performance. The evaluation of executive functions is another gap that could be considered in future research on the subject. In spite of these limitations, we think that the obtained results allow to support the hypothesis of the effectiveness of the syllabic highlight in the development of the ability to recognize words. Future investigations that consider other experimental designs, as well as the study of the effects of intervention programs using this and other strategies of syllabic segmentation, may contribute to a better understanding of the syllable's role in the initial reading learning.

\section{References}

Armitage, P., Berry, G., \& Matthews, J. N. S. (2002). Statistical methods in medical research. (4th ed.). Massachusetts: Blackwell Science. (Original work published in 1971)

Barrera, S. D., \& Santos, M. J. (2014). Influência da consciência fonológica na aprendizagem da leitura e escrita: o que dizem as pesquisas brasileiras. In J. P. Oliveira, T. M. S. Braga, F. L. P. Viana, \& A. S. Santos (Eds), Alfabetização em países de língua portuguesa: pesquisa e intervenção (pp. 27-42). Curitiba: CRV.

Bhattacharya, A., \& Ehri, L. C. (2004). Graphosyllabic analysis helps adolescent struggling readers read and spell words. Journal of Learning Disabilities, 37(4), 331-348. doi: 10.1177/00222194040370040501
Chetail, F. (2014). Effect of number of syllables in visual word recognition: new insights from the lexical decision task. Language, Cognition and Neuroscience, 29(10), 1249-1256, doi: 10.1080/ 23273798.2013.876504

Chetail, F., \& Mathey, S. (2009a). Activation of syllable units during visual recognition of french words in grade 2. Journal of Child Language, 36(4), 883-894. doi: 10.1017/S0305000908009197

Chetail, F., \& Mathey, S. (2009b). The syllable frequency effect in visual recognition of french words: a study in skilled and beginning readers. Reading and Writing, 22(8), 955-973. doi: 10.1007/ s11145-008-9135-9

Coltheart, M. (2013). Modelando a leitura: a abordagem da dupla rota. In M. Snowling \& C. Hulme (Eds), A ciência da leitura (pp. 24-41). Porto Alegre: Artes Médicas.

Cunningham, A. E. (2006). Accounting for children's orthographic learning while reading texts: Do children self-teach? Journal of Experimental Child Psychology, 95(1), 56-77. doi: 10.1016/ j.jecp.2006.03.008

Dancey, C., \& Reidy, J. (2006). Estatística sem matemática para psicologia (3rd. ed., pp. 254-259). Porto Alegre: Artmed.

Doignon-Camus, N., \& Zagar, D. (2006). Les enfants en cours d'apprentissage de la lecture perçoivent-ils la syllabe à l'écrit? Canadian Journal of Experimental Psychology, 60(4), 258-274. doi: 10.1037/cjep2006024

Doignon-Camus, N., \& Zagar, D. (2014). The syllabic bridge: the first step in learning spelling-to-sound correspondences. Journal of Child Language, 41(5), 1147-1165.doi: 10.1017/S0305000913000305

Duncan, L. G., Colé, P., Seymour, P. H., \& Magnan, A. (2006). Differing sequences of metaphonological development in French and English. Journal of Child Language, 33(2), 369-399. doi: 10.1017/S030500090600732X

Ecalle, J., \& Magnan, A. (2007). Development of phonological skills and learning to read in French. European Journal of Psychology of Education, 22(2), 153-167. Retrieved from https://link.springer.com/ content/pdf/10.1007\%2FBF03173519.pdf

Ecalle, J., Magnan, A., \& Calmus, C. (2009). Lasting effects on literacy skills with a computer-assisted learning using syllabic units in low-progress readers. Computers \& Education, 52(3), 554-561. doi: 10.1016/j.compedu.2008.10.010

Ehri, L. C. (2013). O desenvolvimento da leitura imediata de palavras: fases e estudos. In M. J. Snowling \& C. Hulme (Eds.), A ciência da leitura (pp. 153-172). Porto Alegre: Penso.

Ehri, L. C., \& Roberts, T. (2006). The roots of learning to read and write: acquisition of letters and phonemic awareness. In D. Dickinson \& S. Neuman (Eds.), Handbook of early literacy research (Vol. 2, pp. 113-131). New York: Guilford Press.

Ellis, A. W., \& Young, A. W. (2014). Human cognitive neuropsychology (classic edition). London: Pychology Press.

Espírito-Santo, H., \& Daniel, F. (2015). Calcular e apresentar tamanhos do efeito em trabalhos científicos (1): As limitações do $p<0,05$ na análise de diferenças de médias de dois grupos. Revista Portuguesa de Investigação Comportamental e Social, 1(1), 3-16. doi: 10.7342/ismt.rpics.2015.1.1.14

Kim, Y. S., Petscher, Y., Foorman, B. R., \& Zhou, C. (2010). The contributions of phonological awareness and letter-name knowledge to letter-sound acquisition: A cross-classified multilevel model 
Effects of a syllabic highlight technique in word reading of beginning readers

approach. Journal of Educational Psychology, 102(2), 313-326. doi: 10.1037/a0018449

Kyte, C. S., \& Johnson, C. J. (2006). The role of phonological recoding in ortographic learning. Journal of Experimental Child Psychology, 93(2), 166-185. doi: 10.1016/j.jecp.2005.09.003

Maluf, M. R. (2005). Ciência da leitura e alfabetização infantil: um enfoque metalinguístico. Boletim da Academia Paulista de Psicologia, 25(2), 55-62. Retrieved from https://www.redalyc.org/ pdf/946/94625210.pdf

Mansur-Alves, M., Flores-Mendoza, C., \& Tierra-Criollo, C. J. (2013). Evidências preliminares da efetividade do treinamento cognitivo para melhorar a inteligência de crianças escolares. Psicologia: Reflexão e Crítica, 26, 423-434. doi: 10.1590/S0102-79722013000300001

Massad, E., Ortega, N. R. S., \& Silveira, P. S. P. (2004). Métodos quantitativos em medicina. Manole Ltda.

Morais, J. (2003). Levels of phonological representation in skilled readin and in learning to read. Reading and Writing, 16(1-2) 123-151. Retrieved from https://link.springer.com/content/ pdf/10.1023\%2FA\%3A1021702307703.pdf

Morais, J, Leite, I., \& Kolinsky, R. (2013). Entre a pré-leitura e a leitura hábil: condições e patamares da aprendizagem. In M. R. Maluf \& C. Cardoso-Martins (Eds), Alfabetização no século XXI: como se aprende a ler e a escrever (pp. 17-38). Porto Alegre: Penso. Retrieved from http://hdl.handle.net/10174/10434

Nation, K., Angell, P., \& Castles, A. (2007). Orthographic learning via self-teaching in children learning to read english: effects of exposure, durability, and context. Journal of Experimental Child Psychology, 96(1), 71-84. doi: 10.1016/j.jecp.2006.06.004

Pritchard, S. C. (2012). Incorporating learning mechanisms into the DualRoute Cascaded (DRC) model of reading aloud and word recognition (PHD Thesis, Macquarie University, Australia). Retrieved from https://trove.nla.gov.au/work/186648343?q\&versionld=203187664

Salles, J. F.; Piccolo, L. R.; \& Mina, C. S. (2017). LPI - Avaliação da Leitura de Palavras e Pseudopalavras Isoladas para Crianças de $1^{\circ}$ ao $7^{\circ}$ ano do EF (1st. ed. vol. 1) São Paulo: Vetor.

Salles, J. F., Piccolo, L. R., Zamo, R. S., \& Toazza, R. (2013). Normas de desempenho em tarefa de leitura de palavras/pseudopalavras isoladas (LPI) para crianças de $1^{\circ}$ ano a $7^{\circ}$ ano. Estudos e Pesquisas em Psicologia, 13(2), 397-419. doi: 10.12957/epp.2013.8416

Santos, A. A. A., \& Lima, T. H. (2017). Exploratory and confirmatory factor analysis of the Roteiro de Avaliação da Consciência Fonológica, a phonological awareness test. Estudos de Psicologia, 34(2), 211-218. doi: 10.1590/1982-02752017000200003

Sargiani, R. D. A. (2016). Fases iniciais da aprendizagem da leitura e da escrita em português do Brasil: efeitos de fonemas, gestos articulatórios e sílabas na aquisição do mapeamento ortográfico (Doctoral Thesis, Universidade de São Paulo, São Paulo). Retrieved from www. teses.usp.br/teses/disponiveis/47/47131/tde-07102016-182310

Seabra, A. G., \& Capovilla, F. C. (2010). Teste de competência de leitura de palavras e pseudopalavras. São Paulo, SP: Memnon

Seymour, P. H. (2013). O desenvolvimento inicial da leitura em ortografias europeias. In M. Snowling \& C. Hulme (Eds). A ciência da leitura (pp. 314-333). Porto Alegre: Penso.

Shany, M., \& Share, D. L. (2011). Subtypes of reading disability in a shallow orthography: a double dissociation between accuracydisabled and rate-disabled readers of Hebrew. Annals of Dyslexia, 61(1), 64-84. doi: 10.1007/s11881-010-0047-4

Share, D. L. (1995). Phonological recoding and self-teaching: Sine qua non of reading acquisition. Cognition, 55(2), 151-218. doi: 10.1016/0010-0277(94)00645-2

Snowling, M., \& Hulme, C. (2013). A ciência da leitura. Porto Alegre: Penso.

Siccherino, L. A. F. (2017). Consciência fonológica e aprendizagem da linguagem escrita. In M. R. Maluf \& M. J. Santos (Eds), Ensinar a ler: das primeiras letras à leitura fluente. (pp. 93-104). Curitiba: CRV.

Tunmer, W. E., \& Chapman, J. W. (2012). Does set for variability mediate the influence of vocabulary knowledge on the development of word recognition skills? Scientific Studies of Reading, 16(2), 122-140. doi: 10.1080/10888438.2010.542527

Yoncheva, Y. N., Wise, J., \& McCandliss, B. (2015). Hemispheric specialization for visual words is shaped by attention to sublexica units during initial learning. Brain and Language, 145, 23-33. doi 10.1016/j.bandl. 2015.04.001

Ziegler, J. C., Perry, C., Jacobs, A. M., \& Braun, M. (2001). Identical words are read differently in different languages. Psychological Science, 12(5), 379-384. doi: 10.1111/1467-9280.00370

Wania Nogueira Lopes, Mestre em Psicologia na área Saúde

e Desenvolvimento Humano pela Universidade de São Paulo, Ribeirão Preto, é Docente da Secretaria da Educação do Estado de São Paulo - SEE-SP. Endereço para correspondência: Av. Bandeirantes, 3.900, Monte Alegre- Ribeirão Preto - SP. CEP: 14.040-901. Telefone: (16) 3315-3797. Email: lopeswania@yahoo.com.br

Sylvia Domingos Barrera, Doutora em Psicologia Escolar e do Desenvolvimento Humano pela Universidade de São Paulo - USP, é Professora na Universidade de São Paulo - USP, Ribeirão Preto. Email: sdbarrera@ffclrp.usp.br

Recepted in 10.jul.18 Revised in 21.jun.19 Accepted in 13.dec.19 